\title{
МОНГОЛ УЛСЫН ГАДААД БОДЛОГЫН “ГУРАВДАГЧ ХӨРШ”-ИЙН АСУУДАЛД
}

Ц.Лхам

ШУА-ийн Олон улс судлальгн хүрээлэнгийн эрдэм шинжсилгээний ажсилтан Цахим шуудан:lkham16@yahoo.com

Монгол Улсын $\mathrm{XX}$ зууны түүхээс харахад Монгол Улсын гадаад орчны нөхцөл байдалд томоохон өөрчлөлт явагдаж, Монгол Улс харьцангуй бие даасан гадаад бодлого явуулах боломж бүрдэх бүрд гуравдагч улсуудтай холбоо тогтоохыг оролдсон байдаг. Тухайлбал, 1911 онд Богд хаант Монгол Улсыг байгуулсны дараахан Гадаад хэргийг бүгд ерөнхийлөн шийтгэх яамнаас Франц, Англи, Герман, АНУ, Бельги, Япон, Дани, Нидерланд, Австри гэсэн есөн улсад ноот бичиг илгээж, дипломат төлөөлөгчид солилцох, харилцан гэрээ байгуулах, худалдаа нэвтрүүлэх саналыг тавьж байв. ${ }^{1}$

1921 онд хувьсгалт Монгол Улсыг байгуулсны дараа Ардын Засгийн газрын Гадаад яамнаас Монгол Улсыг тусгаар тогтносон тухай гадаад олон улсуудад тунхаг бичиг илгээсэн ${ }^{2}$, Европын орнуудад оюутан сурагчдаa суралцуулж эхэлсэн, аж үйлдвэрийн мэргэжилтнүүдийг урьж авчирсан зэрэг нь мөн л өрнө, дорнын гуравдагч улсуудад хандан, ойртохыг оролдсон хэрэг байлаа.

Харин хөгжингүй орнуудтай харилцаагаа хөгжүүлэхийг эрмэлзсэн гуравдахь удаагийн оролдлого нь үндсэндээ 1985 оноос эхлэн үргэлжилж, эдүгээ “гуравдагч хөрш”-ийн бодлого хэмээн албан ёсны баримт бичгүүдэд томъёологдон хэрэгжих болсон байна. Энэхүү гуравдахь удаагийн оролдлого нь “гуравдагч хөрш”ийн бодлого болон хөгжихөд тухайн уеийн Монголын гадаад орчны томоохон 1 Д.Уламбаяр, Монгол Улсын “гуравдагч хөрш"'-ийн бодлого: онол-түүх, орчин үеийн зангилаа асуудал, 2011 он, Улаанбаатар.

2 Мөн тэнд өөрчлөлт, төр засгийн бодлого шийдвэр, улс орны дотоод хөгжил дэвшил гэсэн үндсэн хүчин зүйлс нөлөөлсөн болохыг энэХүҮ илтгэлдээ харуулах болно.

Мөн энэхүү түүхэн үйл явцыг нэгтгэн хараад, Монгол Улсын “гуравдагч хөрш"ийн бодлого гэдэг нь ямар нэгэн онол, урсгалын үндсэн дээр бус харин түүхэн нугачаан дунд амьдралын эрхээр буй болсон монгол философи юм гэж дүгнэж байна.

ЗХУ-ын өөрчлөлт шинэчлэлт ба Монгол Улсын “гуравдагч хөрш"-ийн бодлогын урьдач өмнөх үе

1985 онд М.С.Горбачев зөвлөлтийн нам, төрийн удирдлагад гарч, өөрчлөлт шинэчлэлтийн үйл явцыг эхлүүлсэн. Улс төрийн шинэ сэтгэлгээ гэж нэрлэсэн М.С.Горбачевын гадаад бодлогын шинэ номлол ямар ч атугай социалист орнуудаас гадаад харилцаандаа ангийн эрх ашгийн үүднээс ханддаг байсан зарчмыг халж, нийт хүн төрөлхтний үнэт зүйлсийг эрхэмлэх зарчмыг тэргүүн зэрэгт тавих болсон нь Монгол Улсын хувьд үнэхээр таатай хэрэг байв.

Тодруулбал, социализмын үйл хэргийг хамгаалах нэрийдлээр нэг нь бусдынхаа дотоод хэрэгт оролцохыг зөвтгөсөн агуулга бүхий “Брежневийн номлол” гэгч бодлогоос М.С.Горбачев татгалзсан ${ }^{3}$ нь социалист хамтын нөхөрлөлд хамаарагч улсууд, түуний дотор БНМАУ-ын эрх баригч намд 3 М.С.Горбачев, Жизнь и реформы, Москва 1995, 311-312 дугаар тал; М.Дүгэрсүрэн, Ц.Гомбосүрэн, Монгол Улсын ХХ зууны гадаад бодлогын түҮхэн тойм, Улаанбаатар 2004. 
үндэснийхээ язгуур эрх ашгийг дээдэлсэн бодлого явуулах боломжийг тодорхой хэмжээгээр нээж өгсөн билээ. ${ }^{4}$

Үүний эхний үр дүн болж 1986 оны MAXH-ын XIX их хурлаас “капиталист олон улс орнуудтай харилцаагаа хэвийн болгох" тухай шийдвэрийг анх удаа гаргасан байна. ${ }^{5}$

1988 оны МАХН-ын Төв Хорооны V Бүгд Хурал дээр МАХН-ын Төв Хорооны ерөнхий нарийн бичгийн дарга Ж.Батмөнх хэлэхдээ, улс орны дотоод амьдралын тулгамдсан асуудлыг шийдвэрлэхийн тулд үзэл суртлын болон бусад ялгааг шалтаг болгохгүйгээр харилцан ашигтай байх зарчим баримтлан гурав дахь орнууд, юуны өмнө өндөр хөгжилтэй өрнөдийн орнуудтай эдийн засгийн гадаад харилцаа, хамтын ажиллагааг хөгжүүлэх нь манай орны хэрэгцээ, үндэсний эрх ашигт бүрэн нийцнэ гэсэн байдаг. ${ }^{6}$

Нам, төрийн дээрх бодлогыг хэрэгжүүлж, манай улс 1987 онд АНУтай, 1989 онд Европын Холбоотой, 1990 онд БНСУ-тай тус тус дипломат харилцаа тогтоосны зэрэгцээ 1986 онд Италийн ГЯЯны орлогч сайд, Англи, Швед, ХБНГУ-ын ГЯЯ-ны төлөөлөгчид, 1987 онд Францын ГЯЯ-ны орлогч сайд БНМАУ-д айлчилсан, БНМАУ-ын ГЯЯ-ны сайд М.Дүгэрсүрэн 1987 онд Япон, Австралид, ГЯЯ-ны орлогч сайд Х.Олзвой 1988 онд Англи, ХБНГУ, Италид айлчилсан бол харин Японы ГЯЯ-ны сайд 1989 онд Монголд тус тус айлчилсан байна. 1988 онд ГЯЯны сайд Ц.Гомбосүрэн АНУ-ын Төрийн нарийн бичгийн дарга Ж.Шульц, 1989 онд Ж.Бейкертэй тус тус уулзсан байна. ${ }^{7}$

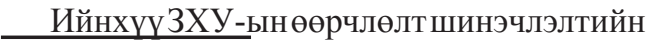

4 М.Дүгэрсүрэн, Ц.Гомбосүрэн, Монгол Улсын ХХ зууны гадаад бодлогын түүхэн тойм, Улаанбаатар 2004, 114 дүгээр тал.

5 МАХН-ын ХІХ Их хурльн материальн эмхэтгэл, Улаанбаатар 1987.

6 Гадаад харилцааны өргөн боломжийс дҮҮрэн ашиглая, Үнэн, 1989 оны 1 дүгээр сарын 5-ны өдөр, №4(17221), 1 дүгээр тал.

7 М.Дүгэрсүрэн, Ц.Гомбосүрэн, Монгол Улсын ХХ зууны гадаад бодлогын түҮхэн тойм, Улаанбаатар 2004, 122 дугаар тал. үйл явц, М.С.Горбачевын гадаад бодлогын шинэ номлолын үр нөлөөгөөр БНМАУ харьцангуй чөлөөтэй хөдлөх боломжийг олж, 1980-аад оны сүүлч үеэс өрнөдийн, өндөр хөгжилтэй гуравдагч орнуудтай хамтын ажиллагаагаа идэвхжүүлж эхэлсэн байна. Үүнийг цаашдын “гуравдагч хөрш”ийн бодлогын урьдач өмнөх үе гэж үзэж болох юм.

Гэхдээ эдийн засгийн хямралын анхны шинж тэмдгүүд илэрч байсан энэ үед уг дотоодын тулгамдсан асуудлыг шийдвэрлэхэд эл бодлого чиглэгдэж, гуравдагч улсуудтай эдийн засгийн хамтын ажиллагааг хөгжүүлэх зорилт тавьж байжээ.

\section{“Гуравдагч хөрш”-ийн бодлогын эхлэл тавигдсан нь}

1990-ээд оны эхэн үе гэхэд олон улсын харилцаанд ноёлсон хоёр туйлт тогтолцооны Потсдамын эрин үе эцэс болж, Монголын гадаад орчин эрс өөрчлөгдсөн.

Хоёр системийн сөргөлдөөн дайсагналцал үгүй болж, ЗХУ задран унаж, Монгол Улс социалист чиг баримжаанаас татгалзан, Зөвлөлтийн цэрэг Монголоос гарч, Орос-Хятадын харилцаа хэвийн болсноор манай улс үндэсний ашиг сонирхлоо дээдэлсэн, бие даасан гадаад бодлого явуулах боломжтой болсон ч нөгөө талаар энэ үе нь дотоодын эдийн засгийн хямрал огцом гүнзгийрч, 1989 онд 4,2 хувьтай байсан эдийн засгийн өсөлт 1990 онд -2,5 хувь болж, мөнгөний ханш хурдацтай унаж, эскпорт буурч, ${ }^{8}$ Монгол Улс аюулгүй байдал, санхүү, эдийн засгийн хувьд тулж түших хүчин үгүй болсон үе байв. Энэ үед эдийн засгийн хямралаас гарахад эн тэргүүнд гадаадын тусламж, дэмжлэгийг олох зайлшгүй шаардлагатай байв.

8 Ц.Цэрэнчимэд, Монгол орны эдийн засаг, Үнэн, 1996 оны 6 дугаар сарын 17, №70(18521), 5, 6 дугаар тал; Ц.Цэрэнчимэд, Монгол орны эдийн засаг, нийгмийн түүхэн үйл яви, байдал, Үнэн, 1999 оны 4 дүгээр сарын 28-29-ний өдөр, №47, 3 дугаар тал. 
Мөн энэ үед Монгол Улс аюулгүй байдлаа хэрхэн хангах тухай хувилбаруудыг дэвшүүлж эхэлж байлаа. Тухайлбал, нэгдүгээрт, Монгол Улс байнгын төвийг сахих бодлого баримтлах, хоёрдугаарт, Монголын аюулгүй байдлын талаар ЗХУ, БНХАУ-ын хамтын баталгаa гаргуулах, гуравдугаарт, аюулгүй байдлын олон улсын баталгаа бий болгох, дөрөвдүгээрт, хоёр хөрш оронтойгоо итгэлцлийг тууштай бэхжүүлэх замаар геополитикийн тэнцвэр барих, ашиг сонирхлыг тэнцвэртэй байлгах бодлого баримтлах, чингэхдээ эдийн засгийн гадаад харилцаанд ганц нэг улсын монопольчлолыг арилгаж, олон янзын түнштэй болох зэрэг хувилбар дэвшигдэж байлаа. ${ }^{9}$

Зөвлөлт-Хятадын 1989 оны 5 дугаар сарын хамтарсан мэдэгдэлд, бие биеийн эсрэг ямар нэгэн хэлбэрээр түүний дотор нөгөө талтай хил залгаа гуравдагч орны газар нутаг, ус, агаарын орон зайг ашиглан хүч хэрэглэх буюу хүч хэрэглэхээр заналхийлэхгүй хэмээн зарласан, ${ }^{10}$ хоёрдугаарт, 1990 оны 5 дугаар сард БНМАУ-ын АИХ-ын Тэргүүлэгчдийн дарга П.Очирбат БНХАУ-д айлчилж, хоёр тал энх тайвнаар зэрэгцэн орших таван зарчим дээр үндэслэн хоёр орны сайн хөршийн харилцааг хөгжүүлэх, хоёр орны хилийг энх тайвны хил болгохоо нотлон мэдэгдсэн ${ }^{11}$ зэрэг нь Монгол Улсын хувьд аюулгүй байдлын гадаад таатай орчинг бүрдүүлэхэд чухал хувь нэмэр болсон төдийгүй дээрх 4 хувилбараас хамгийн сүүлчийн хувилбарыг сонгон авахад ихээхэн түлхэц үзүүлсэн билээ.

Энэ үед АНУ-ын Төрийн нарийн бичгийн дарга Ж.Бейкер Монгол Улсад айлчлан ирээд, “БНМАУ хоёр том хөрштэй. АНУ тэдний аль нэгтэй харилцахдаа танай харилцаанд сэв суулгахыг боддоггүй. 9 Ж.Энхсайхан, БНМАУ-ылн аюулгүй байдльн баталгааны олон улсын эрх зүйн үндсийг бүрдүүлэх хэтийн төлөв, Аюулгүй байдал, хөгжлийн асуудлууд, 1990 №2, 3-4 дүгээр тал.

10 Мөн тэнд, 7 дугаар тал.

11 Үйл явдльлн тойм, Аюулгүй байдал, хөгжлийн асуудлууд, 1990 №1.
Танай улс АНУ-ыг оролцуулан гурван том улстай сайн харилцаатай байж болох юм"12 гэж хэлсэн нь ерөнхийдөө өмнө дурдсан хувилбаруудаас хамгийн сүүлчийн хувилбар тодрон гарахад ихээхэн нөлөө үзүүлсэн төдийгүй цаашид энэ нь “гуравдагч хөрш”ийн гэсэн нэр тодотголыг олох эх үндсийг тавьж өгсөн болов уу. Өөрөөр хэлбэл энэ үеэс “гуравдагч хөрш” гэдэг нэр томъёо нь өргөн дэлгэр, гүн гүнзгий утга санааг илэрхийлж, өндөр хөгжилтэй, өрнөдийн орнуудтай зөвхөн эдийн засгийн харилцааг хөгжүүлээд зогсох бус бусад салбарт ч хамтын ажиллагааг хөгжүүлэх нь зүйтэй гэсэн чиглэлийг нэмж өгсөн болов уу.

Дүгнэн хэлэхэд, БНМАУ-ын зүгээс 1986-1989 оны хооронд өндөр хөгжилтэй, капиталист орнуудтай эдийн засгийн харилцаагаа идэвхжүүлэх бодлого нь 1990 оноос хойш улам баяжин "гуравдагч хөрш”-ийн бодлого руу шилжсэн болов уу гэж дүгнэж болохоор байна.

Аюулгүй байдлын энэ үзэл санаа ийнхүҮ “гуравдагч хөрш”-ийн санаагаар баяжин олон тулгуурт бодлого болон хөгжсөн бөгөөд энэхүҮ олон тулгуурт бодлого нь 1994 оны аюулгүй байдал, гадаад бодлогын үзэл баримтлалд тусгалаа олсон байна.

\section{“Гуравдагч хөрш"-ийн бодлого үндсэн баримт бичгүүдэд тусгагдсан нь}

1994 оны Монгол Улсын Аюулгүй байдлын үзэл баримтлалд, Монгол Улс гадаад харилцаандаа олон түнштэй байх бодлого явуулах тухай, Монгол Улс хоёр хөрш оронтой харилцах асуудалд тэргүүн зэргийн ач холбогдол өгч, тэнцвэртэй харилцах зарчим баримтлах тухай, нөлөө бүхий орнуудтай зөвлөлдөж байх, нөлөө бүхий улсуудын стратегийн сонирхлыг Монголд буй болгох бодлого явуулах тухай ерөнхийлөн заасан байдаг ${ }^{13}$ бол харин

12 Үйл явдльн тойм, Аюулгүй байдал, хөгжлийн асуудлууд, 1990 №2, 47 дугаар тал.

13 Монгол Улсын Үндэсний аюулгүй байдлын Үзэл баримтлал, 1994 оны 6 дугаар сарын 30, Төрийн мэдээлэл, 9/1994, 781 дүгээр тал. 
үүнийг нарийвчлан 1994 оны Монгол Улсын гадаад бодлогын үзэл баримтлалд, “Монгол Улс гадаад улс төрийн бодлогодоо ... олон тулгуурт бодлого явуулна." гэжээ. ${ }^{14}$

Энэхүу гадаад бодлогын олон тулгуур гэдэг нь гадаад бодлогын үндсэн чиглэлүүдийг нэрлэж байгаa бөгөөд 1994 оны гадаад бодлогын үзэл баримтлалд үндсэн 6 чиглэлийг харин гадаад бодлогын 2011 оны шинэ үзэл баримтлалд хуучин социалист орнуудын чиглэл хасагдаж үндсэн 5 чиглэлийг багтаасан байна. ${ }^{15}$

Эдгээр тулгуурын хоёр дахь чиглэл болох өрнө, дорнын өндөр хөгжилтэй орнуудтай харилцах бодлого нь эдүгээгийн “гуравдагч хөрш”-ийн бодлогын үндсэн суурь болж байна.

2011 оны Гадаад бодлогын шинэ үзэл баримтлалд “АНУ, Япон, Европын Холбоо, Энэтхэг, БНСУ, Турк зэрэг өрнө, дорнын улс, холбоотой гуравдагч хөршийн бодлогын хүрээнд түншлэлийн харилцаа, хамтын ажиллагааг өргөжүүлэн хөгжүүлэх чиглэлийг баримтална" 16 хэмээн зааснаас үзэхэд гадаад бодлогын үндсэн баримт бичигт “гуравдагч хөрш” гэсэн ойлголт анх удаа албан ёсоор томъёологдон орсон байна. Иймд бидний зүгээс “гуравдагч хөрш”ийн бодлогыг нарийвчлан судлах, нэгдсэн ойлголтод хүрэх зайлшгүй шаардлага бий болоод байна.

ЭнэхүҮ түүхэн үйл явцыг ерөнхийлөн харахад Монгол Улсын “гуравдагч хөрш”ийн бодлого гэдэг нь улс орныхоо дотоод тулгамдсан асуудлыг шийдвэрлэхийн тулд дэлхийн хүчирхэг улсуудтай харилцаа, хамтын ажиллагааг гүнзгийрүүлэх, тэдний бодит сонирхлыг өөртөө бий болгох, хоёр хөрш оронтойгоо тэнцвэртэй харилцах замаар хязгаарлагдмал гадаад орчиндоо нэмэлт таатай нөхцлийг бүрдүүлэн ашиглах гэсэн бодлого юм.

14 Монгол Улсын гадаад бодлогын Үзэл баримтлал, 1994 оны 6 дугаар сарын 30, Төрийн мэдээлэл, 9/1994, 805-806 дугаар тал.

15 Монгол Улсын гадаад бодлогын Үзэл баримтлал, 2011 оны 2 дугаар сар

16 Монгол Улсын гадаад бодлогын үзэл баримтлал, 2011 онь 2 дугаар сар

\section{Дүгнэлт}

Монгол Улсын хувьд өндөр хөгжилтэй, гуравдагч орнуудтай ойртон нөхөрлөх сонирхол өнгөрсөн зууны туршид байсаар байжээ. Харин үүнийгээ хэрэгжүүлэх таатай нөхцөл тэр бүр бүрдээд байгаагүй бөгөөд зөвхөн Монгол Улс харьцангуй бие даасан гадаад бодлого явуулах боломж тохиосон тэр үед л явуулахыг оролдож байсан байна.

Эхний хоёр удаагийн зурвасхан богино үеийн оролдлого олигтой амжилтанд хүрч чадаагүй боловч харин гуравдахь удаагийн оролдлого харьцангуй амжилттай явагдаж байна.

Ийнхүу амжилттай явагдах үндэс нь Монгол Улс бие даасан гадаад бодлого явуулах боломжтой болсны үндсэн дээр хоёр хөрш оронтойгоо харилцан ашигтай, хамтын ажиллагааны зарчмаар найрсаг харилцааг хөгжүүлж, харьцангуй тэнцвэртэй байдлыг бий болгосон явдал юм.

1990 оноос явуулж буй Монгол Улсын “гуравдагч хөрш”-ийн бодлого нь тухайн үеийн Монголын эдийн засгийн хямралт байдлыг даван гарахад чиглэгдэж байсан бөгөөд эдүгээ ч “гуравдагч хөрш”ийн орнуудтай эдийн засгийн хамтын ажиллагааг хөгжүүлэх явдал эл бодлогын үндсэн чиглэл хэвээр байна.

Үйл явдлын өрнөлөөс харахад “гуравдагч хөрш”-ийн бодлогод нөлөөлөх гол хүчин зүйлс нь нэгдүгээрт, Монгол Улсын гадаад орчны томоохон өөрчлөлт, хоёрдугаарт, төр, засгийн бодлого шийдвэр, гуравдугаарт, улс орны дотоод хөгжил дэвшил гэсэн дүгнэлтийг хийж байна. Иймд бидний зүгээс “гуравдагч хөрш”-ийн бодлогыг цаашид амжилттай явуулахын тулд улсынхаа гадаад орчны өөрчлөлтийг ажиглан судлах буюу хоёр хөрш болон “гуравдагч хөрш” орнуудын гадаад, дотоод тулгамдсан асуудал, зорилт, хэтийн төлвийг судлах шаардлагатай юм. 


\section{Ашигласан бүтээлийн жагсаалт}

1. Гадаад харилцааны өргөн боломжийг дүүрэн ашиглая, Үнэн, 1989 оны 1 дүгээр сарын 5-ны өдөр, №4 (17221), 1 дүгээр тал.

2. Горбачев М.С., Жизнь и реформы, Москва 1995, 311-312 дугаар тал;

3. Дүгэрсүрэн М., Гомбосүрэн Ц., Монгол Улсын ХХ зууны гадаад бодлогын түүхэн тойм, Улаанбаатар 2004.

4. МАХН-ын ХІХ Их хурлын материалын эмхэтгэл, Улаанбаатар 1987.

5. Монгол Улсын гадаад бодлогын үзэл баримтлал, 2011 оны 2 дугаар сар

6. Монгол Улсын гадаад бодлогын үзэл баримтлал, 2011 оны 2 дугаар сар

7. Монгол Улсын гадаад бодлогын үзэл баримтлал, 1994 оны 6 дугаар сарын 30, Төрийн мэдээлэл, 9/1994, 805-806 дугаар тал.

8. Монгол Улсын Үндэсний аюулгүй байдлын үзэл баримтлал, 1994 оны 6 дугаар сарын 30, Төрийн мэдээлэл, 9/1994, 781 дүгээр тал.

9. Уламбаяр Д., Монгол Улсын “гуравдагч хөрш”-ийн бодлого: онол-түүх, орчин үеийн зангилаа асуудал, 2011 он, Улаанбаатар.

10. Үйл явдлын тойм, Аюулгүй байдал, хөгжлийн асуудлууд, 1990 №1.

11. Үйл явдлын тойм, Аюулгүй байдал, хөгжлийн асуудлууд, 1990 №2, 47 дугаар тал.

12. Цэрэнчимэд Ц., Монгол орны эдийн засаг, Үнэн, 1996 оны 6 дугаар сарын 17, №70(18521), 5, 6 дугаар тал; Ц.Цэрэнчимэд, Монгол орньл эдийн засаг, нийгмийн түүхэн үйл яви,, байдал, Үнэн, 1999 оныл 4 дүгээр сарын 28-29-ний өдөр, №47, 3 дугаар тал.

13. Энхсайхан Ж., БНМАУ-ын аюулгүй байдлын баталгааны олон улсын эрх зүйн үндсийг бүрдүүлэх хэтийн төлөв, Аюулгүй байдал, хөгжлийн асуудлууд, 1990 №2, 3-4 дүгээр тал. 